\title{
Online Political Discourse on Facebook: An Analysis of Political Campaign Communication in Austria
}

\author{
Uta Rußmann
}

\section{Key message}

Social media such as Facebook have the capacity to revolutionize public discourse as they encourage citizens to participate in politics and to engage with politicians. However, simply the fact that there is public discussion on political issues says yet nothing about its specific quality. From the viewpoint of Habermas' concept of deliberative democracy (1987) we define that only political discussion, which is oriented towards communicative principles of understanding, can promote the development of a deliberative public sphere. Along an index of quality of understanding (Verständigungsorientierungsindex, VOI) we examine political parties and candidates' Facebook communication ( $N=9428$ posts and comments) during the most recent Austrian elections in Vienna in October 2010. The political discourse is following the principles of a quality of understanding if political actors do not only state their positions, but also give statements of reasons. If, in the case of debatable questions, they present specific proposals for solutions, they deal with others in a more or less respectful way and they express relevant doubts concerning positions and other participants.

\section{Introduction}

Social media is a relatively open communication space that gives (almost) everyone the opportunity to articulate which issues are of concern to him/her. "Because of its horizontal, open, and user-friendly nature" (Brants, 2005, p. 144), it has opened a new arena for more citizens to actively participate in political discourse. For politicians social media like Facebook have considerably increased the possibility to talk directly to the public and thereby strengthen their bond with the public (cf., Gueorguieva, 2008; Williams \& Gulati, 2007). The willingness of political actors to publish information online means that "citizens can easily inform themselves on political issues. Citizens are therefore likely to be better informed prior to deliberation" (Koop \& Jansen 2009, p. 156).

As early as in the mid-1970s, Amitai Etzioni and colleagues (1975) emphasized that electronic media can foster deliberative processes. In a series of telephone conference calls they demonstrate that this electronic medium increases political participation: Electronic meetings are more conducive than face-to-face meetings to letting people exchange their opinions and change their minds; yet, this greater individual freedom did not impede the formation of a final group deci- sion (Etzioni, Laudon \& Lipson, 1975, p. 71; see also p. 70). The authors conclude that electronic meetings can be used as "a mechanism for regular communication and feedback" (Etzioni et al., 1975, p. 73) between citizens (e.g., the American citizenry) and their representatives and "can form authentic consensus essential for democracy” (Etzioni et al., 1975, p. 64). Following the idea of a deliberative democracy, the new way of political exchange on social media can enhance democratic processes as it allows a direct and ongoing dialogue between citizens and their elected representatives. However, the number of citizens engaging in political discussions via social media is still small (compared to the overall Austrian ${ }^{1}$ population) and it is rather limited to those who are interested in political life. Nevertheless, in democratic societies there is a certain collective interest in political processes (Ruß-Mohl, 1994, p. 83 f.) and as John Gastil (2008, p. 8) notes democracy “must cultivate an enlightened understanding of each citizen's interests, it must have a sophisticated means of collecting, processing, and distributing information and experiences among its diverse, large membership". An informed public is essential to the proper functioning of politics. Citizens need to be informed in order to vote intelligently. Furthermore, research examining the effects of everyday offline political conversation on political behavior and knowledge in postcommunist Hungary shows that political discussion within heterogeneous settings as we can find them in social media communities appears to increase people's ability to recognize parties' positions (Lup, 2010, p. 197): “[E]ncountering diverse political views helps people to understand parties' positions more than mere talk or following news do" (Lup, 2010, p. 196).

Today, there is common understanding that social media has considerably increased the quantity of political participation; however, this says nothing about the quality of the online political discourse. Political or public discourse is defined as "public communication about topics and actors related to either some particular policy domain or to the broader interests and values that are engaged" (Ferree et al., 2002, p. 9). The goal of this paper is to investigate how people, in partic-

1 In Austria, about $80 \%$ of the population (age 14 and older) uses the Internet. Today, half of the Internet users use social media of which most (48\%) turn to Facebook. Other social media are rarely visited (e.g. $3 \%$ of Austrian Internet users now use Twitter). Over the last three years, the number of people who use social media on a regular basis constantly increased: social media use among Internet users has tripled between 2009 and 2010 (for more information, see: http://mediaresearch.orf.at/index2.htm?internet/internet aim.htm (retrieved last Sept., 2012) Nevertheless, only a few people turn to social media when searching for political information. 
ular political actors, communicate in online political discussion. Along the index of a quality of understanding (Verständigungsorientierungsindex, VOI) (Burkart \& Rußmann, 2010; Rußmann, 2012) we analyze political campaign communication on Facebook. In the first part of the paper we present the theoretical framework which is based on Habermas' conception of deliberative democracy (1987) as well as previous studies on public discourse (Gerhards, Neidhardt \& Rucht, 1998; Steenbergen et al., 2003; Spörndli, 2004). In the second part of the paper we present an empirical analysis of the communication on political parties and candidates' Facebook profiles during the last four weeks before the 2010 Austrian regional elections in the state of Vienna. The paper concludes with a discussion of the principal findings.

\section{Deliberative discussion}

The idea of deliberative democracy is that citizens and their elected representatives engage in talk with each other (Dahlgren, 2005, p. 149) and thereby contribute to more vibrant public discourse on public issues. Survey results on the use of web forums in the Netherlands show that participants "view web forums as open platforms for discussion in terms of the opinions expressed on the forums" (Witschge, 2008, p. 83); especially compared to traditional media. Moreover, analyzing two online discussion lists in the Netherlands, Hagemann (2002, p. 74) shows that people actually talk about current public issues on discussion lists. Koop and Jansen (2009, pp. 164-167) observed that bloggers were engaged in discussions on substantive issues rather than trivia; whereby they were mainly discussing national and international issues rather than party politics. However, Hagemann (2002) notes that opinions were mainly expressed without supporting arguments. Similar findings are presented by Coleman, Hall, and Howell (2002, p. 8) who examined e-consultation forums in the United Kingdom: The majority of "participants in forums posted messages which simply stated their opinions and very few participants in the forum seemed to use facts in their deliberation". Drawing upon Habermas' theory of rational communication Dahlberg (2001 a) evaluates to which degree online discourse enhances the public sphere. The author investigates five qualitative criteria of a deliberative, democratic discussion: exchange and critique of criticizable moral-practical validity claims, reflexivity, ideal role-taking, sincerity as well as discursive inclusion and equality. Dahlberg concludes that the quality of online discourse falls short of these requirements. Similar results were obtained in an analysis of four Finnish political discussion boards during the last three weeks before the 2007 Finnish parliamentary election. Strandberg (2008, pp. 83-84) found that only a few messages were supported by rational argumentation. Moreover, the analyzed debates showed a relatively low degree of reciprocity and mutual respect. The author concludes that "deliberative ideals are hardly met" $(2008$, p. 83$)$ in the online discussions. However, even though "not all participants make the effort of arguing their positions" (Ruiz et al., 2011, p. 477), it seems that those users who engage in thoughtful discussions enjoy "the exercise of trying the most convincing argument" (Ruiz et al., 2011, p. 484) as noticed by Ruiz, Domingo, Micó, DíazNoci, Meso, \& Masip (2011) who analyzed the democratic quality of citizens' comments in news of five online newspapers (of four Western European countries and the US). Hence, the overall conclusion that we reach with the existing studies is that citizens view and use online forums as platforms for substantive political discussion. However, citizens' online discussions display a low quality of deliberative standards.

The current research assumes as argued by Habermas (1992) that only if the discussion is interaction oriented and permits the circulation of information, positions, arguments and ideas it can lead to a rational consensus of all participants. Thereby, the discourse enhances "the formation of political will (i.e., public opinion)” (Dahlgreen, 2005, p. 148). Gastil (2008, p. 9) noted that deliberation "is not just about the substance of an exchange. Deliberation also refers to the social process of communicating". Citizens have to understand the messages of political actors in order to interpret it and to develop their own opinions, and then they may participate in the political discussion. Due to the Habermasian perspective of a deliberative democracy (1987) there is a public need of understanding.

\section{Indicators of a Quality of Understanding}

In the Theory of Communicative Action (TCA) (1984, 1987, 2001) Habermas examines different speech-acts, thereby defining the rational conditions for mutual understanding in communicative action (Habermas, 1984, p. 305ff.). In everyday communication practice participants need to accept the validity of different demands and claims in order to reach a mutual understanding. They have to validate the discourse. Habermas emphasizes four validity claims (Geltungsansprüche): intelligibility (i.e., participants are convinced of using the proper grammatical rules), truth (i.e., participants are certain that they are talking about something that the partner accepts as real), truthfulness (i.e., participants agree on being honest to each other and on not misleading the partner) and legitimacy (i.e., participants believe that they are acting in accordance to mutually accepted values and norms). The communication process will continue as long as participants do not cast doubt on the fulfillment of the four validity claims. However, like democracy, such an ideal speech situation (Habermas, 1970) "is something that we can use as a critical standard for judging the quality of actual talk, but it is not something humans can live up to" (Gastil, 2008, p. 22). Such conditions hardly ever occur in real-life discourse. In everyday interaction the claims are open to criticism and justification. In particular, election campaigns are times of intensive public discussion about political issues and political parties and their candidates as "election campaigns are among the most important events in the lives of democracies and societies in transition" (Semetko, 2008). Citizens question political parties' behavior and their views on public issues. Political 
actors criticize their opponents and question their legitimacy. Under such conditions it may seem impossible to build rational consensus. In order to reach a mutual understanding, participants enter into a discourse to defend themselves and their position(s). "Each participant must make a sincere effort to make known all information, including their true intentions, interests, needs, and desires, as relevant to the particular problem under consideration (Dahlberg, $2001 \mathrm{a}$ )." In the process of argumentation and dialogue the validity claims are tested for their rational justifiability as true, correct or authentic (Habermas, 1984). In an ideal speech situation, participants will listen to each other, they will justify their position and behavior and participants will offer solutions for the particular problem which leads to a genuine, rational consensus due to the "non-coercive coercion of the better argument" (Habermas, 1992, p. 138-9, 371). Even though, reality often falls short of these ideals, we define that only political discussion, which is oriented towards communicative principles of understanding, can promote the development of a deliberative public sphere. Based on the above and following previous studies on public discourse (Gerhards et al., 1998; Steenbergen et al., 2003; Spörndli, 2004), the following communicative principles of understanding are specified: statement of reasons for positions, proposals for solutions, expressions of respect concerning positions as well as others and doubts on the four validity claims. ${ }^{2}$

\section{Statement of Reasons}

First and foremost, people who speak in public, in particular political actors are trying to convince others of the importance of their issues (Gerhards, 2003, p. 301). They want to persuade others to accept and to support their position. Convincing others is all about explaining their point of view, their behavior and their aims. In political discussions in public spaces like social media participants "should give reasons for [their positions and] decisions, and respond to the reasons that citizens give in return" (Gutmann \& Thompson, 2004, p. 3). Besides the research presented above, there are a few empirical studies examining effects of deliberation in offline political debates (Spörndli, 2004, p. 146 and 177; Steenbergen et al., 2003) that highlight the importance of this principle in order to reach a mutual understanding. For example, Spörndli (2004, p. 145) found in his analysis of debates in the German Conference Committee (Vermittlungsausschuss) that in case of debatable questions, to reach consensus it is essential that arguments are well-explained and logical presented.

\section{Proposals for solutions}

In political discourse participants have different views, ideas and opinions about public issues. Following the idea of deliberative democracy and Habermas's discourse ethics, disputes and conflicts should be solved by reaching a rational consensus through discussion. Hence, ideally, different solutions for the particular problem will be introduced by participants.
Based on the analysis of the abortion discourse in Germany, Gerhards, Neidhardt \& Rucht (1998, p. 118) note that it is common practice in everyday politics that political actors introduce different solutions for a particular problem as they are trying to convince others, e.g. voters, of their position. In the discourse on abortion all political alternatives were outlined in a way that the public was able to follow them.

\section{Respect}

A political discussion requires "maintaining a degree of respect for yourself and your fellow participants" (Gastil, 2008, p. 10). Respect means that participants need to listen to each other and "accept that there are several reasonable viewpoints for many questions" (Spörndli, 2003, p. 3). Participants can question other positions and actions as long as this critique is respectful (Spörndli, 2003, p. 5). They have to treat others "as sincere, competent participants, as long as they do not themselves reject these principles" (Gastil, 2008, p. 10). The empirical analysis of debates in the German Conference Committee shows that in offline debates mutual respect is a factor that has a positive impact within the process of reaching a consensus (Spörndli, 2004, p. 146). Hence, we define respect concerning positions as well as others as another essential condition for mutual understanding in communicative action.

\section{Doubts (validity claims)}

In accordance with the Habermasian perspective of understanding, we assume that in the political discussion now and then participants cast doubt on other participants and their messages. They disbelieve the validity claims. For example: They may doubt the truth of propositions, the truthfulness of the involved political actors as well as the legitimacy of their interests. Hence, this will disrupt the discourse and under such conditions participants will not be able to reach consensus. Thus, by justifying their positions, their behavior or their actions participants will try to resolve these doubts. We distinguish between four types of doubts:

n Intelligibility: Doubts on the intelligibility are expressed if participants question whether the statement of another participant is formulated in such a way that the members of the addressed public will be able to understand it.

2 As critical deliberative theorists have noted, there are other normative and critical approaches to politics that contrast and criticize Habermas' concept of the public sphere-for example: Chantal Mouffe (2000) and her agonistic model of democracy (for the discussion of the different theoretical approaches see also Karppinen, Moe, \& Svensson, 2008). Due to the limit of space these are not discussed within the paper which main goal is to introduce a methodological concept to analyze the quality of online political discourse using Habermas' discursive ethics as a normative benchmark as it offers a solid normative grounding for the analysis of public discourse. Even though, for example, Wright noticed (2012, p. 245) that "using such a model of deliberation sets an unrealistic goal and measure for debate online", because the "communicative character of the political discussion does not always promote the civic ideal" (Dahlgreen, 2005, p. 151). However, its high standards and principles are useful to define directions of an ideal speech situation. Habermas himself talks of a normative framework toward which the real community can live up to. 
- Truth: Doubts on the truth are expressed if participants question whether a statement pertaining to a specific circumstance (e.g., situation, fact, occurrence) of a participant is a proven fact.

- Truthfulness: Doubts on the truthfulness are expressed if participants claim that another participant is not trustworthy. For example, they allege that someone has lied and/or participants are accused of lacking honesty or integrity.

- Legitimacy: Doubts on legitimacy are expressed if participants question the appropriateness of other participants' actions and their behavior. (Burkart \& Rußmann, 2010)

Figure 1 summarizes the four indicators that allow to operationalize and empirical quantify the quality of understanding of political discussion.

Figure 1: Indicators of a Quality of Understanding

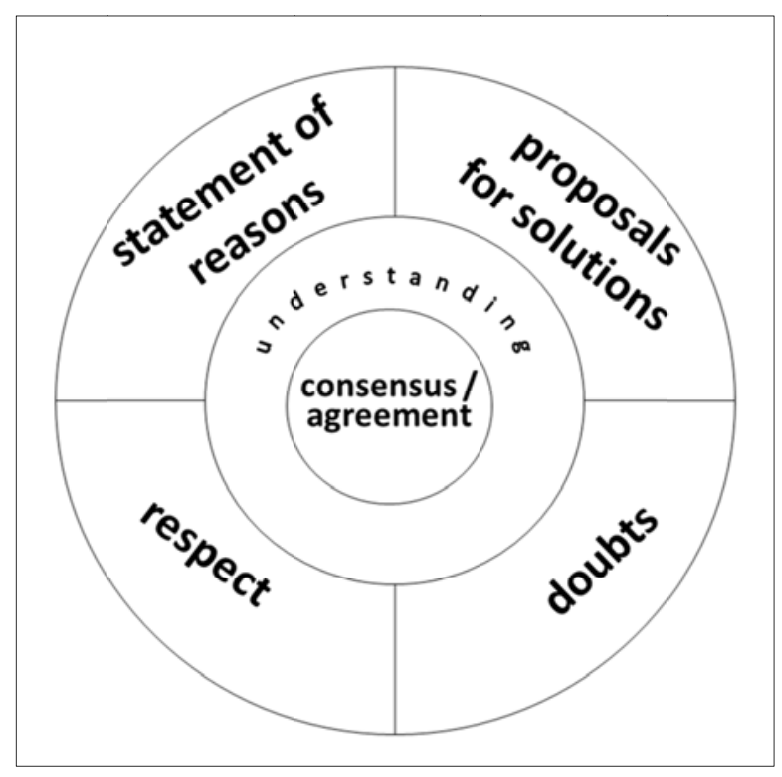

Source: Burkart \& Rußmann, 2009

The level of the quality of understanding of discourse is dependent on the strength of the four indicators (see below): statement of reasons, proposals for solutions, respect and doubts. For example, a high quality of understanding applies if participants, e.g. political actors, a) do not only state their positions on polity, politics and policy issues, but also give statement of reasons; b) (if) in the case of debatable questions on polity, politics and policy issues, they present specific proposals for solutions; c) deal with other participants (e.g., their opponents) in a more or less respectful way; and d) express relevant doubts concerning positions as well as other participants (e.g., their opponents).

As outlined above, citizens have to understand the political message, and then they may engage in the political discourse. Therefore, this article focuses on the question of whether and to what extent do political parties and candidates follow the principles of a quality of understanding in political campaign communication on Facebook?
Based on the notion that participants of social media are constructing and sustaining an online public sphere by involvement and engagement, the following hypothesis is proposed:

H1: The more political actors follow the principles of a quality of understanding, the more will Facebook participants join the political discussion.

\section{Data and method}

\subsection{Sample}

The analyzed material consists of political parties and top candidates' Facebook communication in the most recent Austrian (regional) election campaign in Vienna on October 10, 2010. The first elections in Austria, in which all major and minor political parties in the federal state government used Facebook as campaign tool. Facebook was not just the most frequently used social media, moreover, it was the only social media implemented by all political parties in the federal state government during the election campaign.

The data contains postings, i.e., posts and comments, of the Facebook sites of the Viennese SPÖ (www.facebook.com/ spoewien), the regional party of the Social Democratic Party of Austria (SPÖ) (Figure 2), and of Christine Marek (www.facebook.com/\#!/ChristineMarek), the top candidate of the regional party of the Austrian's People Party (ÖVP), the Viennese ÖVP (Figure 3), as well as postings of the Facebook profiles of Heinz-Christian Strache (www.facebook.com/\#!/ HCStrache), the top candidate of the regional party of the Freedom Party of Austria (FPÖ), the Viennese FPÖ (Figure 4), and of the Viennese Green Party (www.facebook.com/\#!/ diegruenenwien), the regional party of The Greens - The Green Alternative (Figure 5). All posts and comments of the last four weeks before Election Day, respectively, from September 12 to October 2, 2010, have been included in the content analysis. This period was selected as it is considered to be the hot phase of the campaign.

The sample consists of a total of 9428 posts and comments (Table 1). Each post and comment is treated as a single case (unit of analysis).

Table 1. Number of Posts and Comments on Political Actors' Facebook Sites (09-12 to 10-02-2010)

\begin{tabular}{llllll}
\cline { 2 - 6 } & $\begin{array}{l}\text { HC Strache } \\
\text { (FPÖ Vienna) }\end{array}$ & $\begin{array}{l}\text { The } \\
\text { Greens } \\
\text { Vienna }\end{array}$ & $\begin{array}{l}\text { Christine } \\
\text { Marek } \\
\text { (ÖVPVienna) }\end{array}$ & $\begin{array}{l}\text { SPÖ } \\
\text { Vienna }\end{array}$ & $\begin{array}{l}\text { Total } \\
\text { (N) }\end{array}$ \\
\cline { 2 - 6 } $\begin{array}{l}\text { Number of } \\
\text { post } \\
\text { and comments }\end{array}$ & 7807 & 350 & 425 & 846 & 9428
\end{tabular}

Following the content analysis of the Facebook sites of the political parties and top candidates we will compare its output.

The Viennese SPÖ (SPÖ Wien) is the regional party of the Social Democratic Party of Austria (Sozialdemokratische Partei Österreichs, SPÖ), one of the oldest political parties in 
Austria. The centre-left SPÖ is one of the two largest political parties in Austria with the Austrian People's Party (ÖVP). The party has close ties to trade unions (ÖGB) and the Austrian Chamber of Labor. The Viennese SPÖ is one of the biggest city parties worldwide (Der Standard, 2012). Since 1945 the SPÖ governs Vienna and only in 1996 and 2010 the Vienna Social Democrats lost its overall majority. The mayor also has the role of the state governor. The current mayor of Vienna is Michael Häupl who shapes Viennese politics since 1994. Since the elections in 2010 the SPÖ Vienna rules together with the Viennese Green Party.

The Viennese ÖVP (ÖVP Wien) is the regional party of the Austrian People's Party (Österreichische Volkspartei, ÖVP), a Christian democratic and conservative political party in Austria. The ÖVP is the major catch-all party of the centre-right of Austrian politics. In March 2010, Christine Marek was elected as head of the Viennese ÖVP.

The Viennese FPÖ (FPÖ Wien), the regional party of the Freedom Party of Austria (Freiheitliche Partei Österreichs, FPÖ), is a right-wing populist party (Pelinka, 2002). In 2004, Heinz-Christian Strache was elected the leader of the Vienna FPÖ. Since 2005, HC Strache is also the national party leader of the FPÖ. In the 2010 Vienna election campaign, Strache was (once again) accused of xenophobia, but he responded formally in the media to these allegations (Die Presse, 2012). HC Strache's party received about $26 \%$ of the vote in the 2010 Vienna elections ( $2^{\text {nd }}$ place). The party's support was strongest among young people under age 30 .

The Viennese Green Party (Die Grünen Wien) is the regional party of The Greens - The Green Alternative (or the Austrian Green Party; Die Grünen - Die Grüne Alternative). Formed in 1986, the Austrian Green Party is the youngest political party of the four analyzed parties in this study. Apart from ecological issues such as environmental protection, the Greens highlight the importance of rights of minorities. In the 2005 Viennese elections, the Greens Vienna were able to win votes, but they ended up on fourth place, right behind the right-wing Freedom Party (FPÖ).

\subsection{Measurement: Index of a Quality of Understanding}

The index of a quality of understanding (Verständigungsorientierungsindex, VOI) (Burkart \& Rußmann, 2010; Burkart et al., 2010; Rußmann, 2012) serves as a quantitative measure of the quality of understanding of public discourse. The index is based on four indicators: statement of reasons, proposals for solutions, expressions of respect concerning positions as well as others, and doubts. The variables statement of reasons, proposals for solutions and respect are coded on different levels in each unit of analysis (i.e., post or comment on Facebook). Each level is assigned a specific value (see below). In addition, contexts in which doubts on the four validity claims (intelligibility, truth, truthfulness and legitimacy) are expressed will be examined. To allow for quantitative comparison, each doubt was assigned a score: 0 for absence of the doubt in the unit of analysis and 1 for its presence. The scores of the four indicators are aggregated to an index, summarizing the results for each analyzed Facebook site and then were divided by the maximum value that could be reached. The maximum number of points per unit of analysis is $10 .^{3}$ The index of each Facebook site provides an overall evaluation of its quality of understanding.

\section{Level of Statement of Reasons}

In political discourse participants want others to support and legitimize their position, behavior and/or actions; hence, they are explaining, arguing, refuting and pleading their messages. In the process of interaction they need to give sufficient statement of reasons (arguments, justification). Following previous research (Spörndli, 2004, p. 9 f.; Steenbergen et al., 2003, p. 28) we distinguish between four levels of statement of reasons:

$0=$ no statement of reasons is given for a position, the political act or the political behavior

$1=$ generalized statement of reasons: the communicated action or position is embedded in an indefinite, short justification; based on common sense

2 = simple statement of reasons: a reference to a fact; the argument is justified by a single fact

$3=$ specific statement of reasons: the communicated action or position is supported by facts and figures, the opinion of an expert and/or scientific grounding

\section{Level of Proposals for Solutions}

To solve a particular problem under consideration, each participant must make a sincere effort by introducing proposals of solutions. We distinguish between three levels of proposals for solutions:

$0=$ no proposals for solutions are given for a problem under debate

1 = partial proposals for solutions; participants introduce an idea

2 = precise proposals for solutions; a detailed concept is introduced; the actual implementation of the proposal is outlined

\section{Level of Respect}

The index of the level of respect differs from the index of the first two indicators in so far, as the level of respect indicates a negative parameter. To avoid a negative index value and hence, to be able to aggregate the level of respect with the two other only positive evaluated indicators (statement of reasons and proposals for solutions), we assign the value 0 (zero) to the negative attribute of respect, i.e. respectless expressions. Thereby, respectful and explicit respectful expressions are assigned a higher value. We code expressions of respect con-

3 As it never occurred that in a single unit of analysis more than one doubt was coded, the maximum value for doubts per unit of analysis is 1. 
cerning positions as well as other people, their behavior and actions. There are three levels of respect:

0 = respectless expressions; expressions with an explicit negatively valenced attribute

3 = respectful expressions; expressions which are neither negatively nor positively valenced (this applies to every unit of analysis that is neither coded with the code 0 nor with the code 4)

4 = explicitly respectful expressions; expressions with an explicit positively valenced attribute

\section{Types of Doubts}

As introduced above, we distinguish between four types of doubts: intelligibility, truth, truthfulness and legitimacy. In the event that a specific doubt is not determinable it is coded as such. (In our present study this never occurred.) All statements that question these validity claims with regard to a particular communication partner, and therefore address them as problem, are classified as doubts. Doubts are always determined with regard to at least one participant (e.g., politician or political party), statement or proposition.

These four indicators provide an analytical template from which to evaluate the democratic quality of online discourse. The indicators are coded to their appearance in the unit of analysis (i.e., posts and comments). Each expression is coded only once, i.e. in case a participant literally repeats him-/herself in a single post or comment only the first statement is coded.

\section{Results}

To find answers to our research question whether and to what extent political parties and candidates follow the principles of a quality of understanding in political campaign communication on Facebook, first, we have to observe the basic structure of the analyzed Facebook sites. An online discussion will only take place if there is a vibrant exchange of statements, opinions and ideas between its participants, both political actors and citizens. Therefore, the size of the online communities as well as the number of posts and comments will be examined.

\subsection{Size of Community and Number of Postings}

\section{Size of Communities: Number of Facebook Fans}

Taking a closer look at the four analyzed Facebook sites, we found significant differences concerning the number of people who like this, i.e. fans of the Facebook site. At the end of the election campaign, HC Strache (FPÖ) had a total of 65.163 fans, whereas his opponents had mobilized far less citizens via Facebook. Christine Marek (ÖVP) just had 1872 Facebook fans, the site of The Greens Vienna only counted 2000 fans and with 1526 fans the SPÖ Vienna did attract the least amount of people on Facebook. The reason for this great difference in the number of fans between HC Strache and his opponents may be explained by the fact that HC Strache used
Facebook to communicate with the public already for a long time prior the elections. At the beginning of 2010, the Facebook profile of HC Strache already counted 5000 fans. The other three political actors went online just before the election campaign in autumn 2010.

However, comparing the four analyzed Facebook sites, results reveal that the number of fans does not influence the number of active participants - those who were actually engaged in the online political discourse. ${ }^{4}$ Table 2 illustrates that HC Strache did have more Facebook fans than his political opponents, though less than $2 \%$ of them were posting comments. ${ }^{5}$ On the contrary, in the smallest community, SPÖ Vienna, every tenths user contributed at least one message (post and/or comment). Nevertheless, on the analyzed Facebook sites the majority of fans can be described as lurkers as they may read the discussions, but they rarely participate actively. ${ }^{6}$ Overall, $90 \%$ and more of those citizens who are part of a political community on Facebook are only observing the online discourse.

Table 2. Number of Fans and Active Participants on Political Actors' Facebook Sites (09-12 to 10-02-2010)

\begin{tabular}{lccc}
\hline Facebook site & $\begin{array}{c}\text { No. of } \\
\text { fans }\end{array}$ & No. of active participants of all fans* \\
\hline HC Strache (FPÖ Vienna) & N & N & $\%$ \\
\cline { 2 - 4 } The Greens Vienna & 65.163 & 1080 & 1.7 \\
Christine Marek (ÖVP & 2000 & 49 & 2.5 \\
Vienna) & 1872 & 94 & 5 \\
SPÖ Vienna & 1526 & 153 & 10 \\
\hline
\end{tabular}

* Participant posted at least one message (post or comment) on the Facebook site of which he/she is a fan.

\section{Number of Posts and Comments}

Table 3 presents the number of postings on the analyzed Facebook sites. The number of posts was quite similar for the four political actors over the course of the campaign. With a post participants can initiate a new discussion string. The four political actors published between 77 and 94 posts. However, the level of involvement with citizens differed between them: During the four weeks prior to the election day, Christine Marek released on average 2.7 posts per day, HC Strache posted on average 3.1 times per day, the SPÖ Vienna published on average 3.75 postings and comments per day and The Greens Vienna send on average 4.8 messages a day. The greater engagement in the online discussion by The Greens Vienna is explained by the very high, rather unique number of comments being published by the party. In total, they com-

4 Due to the fact that one user can create more than one profile on Facebook, for example, by using fake identities; the number of counted active participants may not apply to the actual number of different users. Nevertheless, we assume that the number of users with more than one profile is rather small.

5 Posts by fans are prohibited on the Facebook site of HC Strache.

6 Some people participate in the way that they like something; i.e. expressing their support by pushing the like-button. 
mented 50 times on citizens' postings. Unlike the other three parties, The Greens Vienna were not only trying to influence the online communication from the top by initiating new discussion strings with a post, they also joined the discussion between citizens. Christine Marek never sent a comment. HC Strache ( 9 comments) and SPÖ Vienna (11 comments) seldom entered the online communication on the level of comments.

Comparing the content (posts and comments) that has been contributed to the online communication by the political actors themselves, Table 3 shows that political actors' involvement in the online communication on their Facebook site was not influenced by the degree of user-generated content. For example, compared to the active participants in his community who, in total, posted 7721 comments HC Strache hardly participated in the online communication. The politician sent only 86 messages to his community members - a total of $1.1 \%$ of all postings on his site. The Greens Vienna contributed about $38 \%$ of all postings to the communication on their Facebook site.

Table 3. Number of Postings on Political Actors' Facebook Sites

\begin{tabular}{lcccccccc}
\cline { 2 - 8 } & $\begin{array}{l}\text { HC Strache } \\
\text { (FPÖ Vienna) }\end{array}$ & $\begin{array}{c}\text { The } \\
\text { Greens } \\
\text { Vienna }\end{array}$ & $\begin{array}{c}\text { Christine } \\
\text { Marek (ÖVP } \\
\text { Vienna) }\end{array}$ & \multicolumn{2}{c}{$\begin{array}{c}\text { SPÖ } \\
\text { Vienna }\end{array}$} \\
\cline { 2 - 9 } & $\mathrm{N}$ & $\%$ & $\mathrm{~N}$ & $\%$ & $\mathrm{~N}$ & $\%$ & $\mathrm{~N}$ & $\%$ \\
$\begin{array}{l}\text { No. of posts by political } \\
\text { actor }\end{array}$ & 77 & 1.0 & 85 & 24.3 & 75 & 17.6 & 94 & 11.1 \\
$\begin{array}{l}\text { No. of comments by poli- } \\
\text { tical actor }\end{array}$ & 9 & 0.1 & 50 & 14 & 0 & 0 & 11 & 1.3 \\
$\begin{array}{l}\text { No. of posts by partici- } \\
\text { pants }\end{array}$ & 0 & 0 & 1 & 0.3 & 17 & 4 & 120 & 14.2 \\
$\begin{array}{l}\text { No. of comments by par- } \\
\text { ticipants } \\
\begin{array}{l}\text { Total number of post } \\
\text { and comments }\end{array}\end{array}$ & 7721 & 98.9 & 214 & 61.4 & 333 & 78.4 & 621 & 73.4 \\
& 7807 & 100 & 350 & 100 & 425 & 100 & 846 & 100
\end{tabular}

Taking a closer look at the content published by active fans, the results reveal that participants preferred using comments as illustrated in Table 3. Only on the Facebook site of the SPÖ Vienna $16 \%$ of the content of fans was in form of a post. This is the only Facebook site on which citizens were trying to initiate new discussion strings by setting posts. HC Strache did not allow posts by participants, or in other words, participants were not supposed to start a new discussion topic. However, the content analysis of the comments of active fans on the HC Strache site reveals that participants initiated new topics among the fans by using the comment function. Yet, to a lesser extent than participants of the SPÖ Vienna community did via the posts.

\section{Postings with and without an Intrinsic Value to the Political Discourse}

Nevertheless, neither the number of active participants nor the number of post and comments does reflect the actual contribution to the political discussion. A political discourse will only take place if there is a vibrant exchange of statements, opinions and ideas between its participants. Therefore, we divided the published posts and comments on the four ana- lyzed Facebook sites in two sections. Thereby, quantifying the extent to which the posts and comments are actually contributing to the online political discourse:

1. Posts and comments without intrinsic value to the political discussion. These are posts and comments that only include a like or a plain encouragement for the political actor, such as good, super, go for it, you are the best, an invitation or information to an upcoming event (e.g. campaign rally, TV debate) or postings that only link to another source of information.

2. Posts and comments with intrinsic value. These are posts and comments that are relevant and substantive for the online discussion (e.g. Gonzalez-Bailon, Kaltenbrunner, \& Banchs, 2010, p. 5) as they focus on public issues. In general, they indicate a statement, an opinion and/or an idea. Only posts and comments with an intrinsic value may contribute to the online political discourse and will be analyzed according to the principles of a quality of understanding.

Table 4 shows that in the Facebook community with the most fans, the one of HC Strache, only a third of the published posts (and comments) contributed to a relevant and substantive discussion. In the three smaller communities more than half to two thirds of all posts and comments have intrinsic value. In general, in Facebook discussions there tends to be a lot of talk without any intrinsic value to the political discourse. Postings without any intrinsic value are very common on Facebook as participants tend to leave only a short remark on other peoples' messages. Nevertheless, these postings show an attempt to participate in the online political discourse.

Table 4. Number of Posts and Comments with and without Intrinsic Value

\begin{tabular}{lcccccccc}
\cline { 2 - 8 } & $\begin{array}{c}\text { HC Strache } \\
\text { (FPÖ Vienna) }\end{array}$ & $\begin{array}{c}\text { The Greens } \\
\text { Vienna }\end{array}$ & $\begin{array}{c}\text { Christine } \\
\text { Marek (ÖVP } \\
\text { Vienna) }\end{array}$ & SPÖ Vienna \\
\cline { 2 - 9 } & $\mathrm{N}$ & $\%$ & $\mathrm{~N}$ & $\%$ & $\mathrm{~N}$ & $\%$ & $\mathrm{~N}$ & $\%$ \\
\cline { 2 - 9 } & 2538 & 32.5 & 196 & 56 & 238 & 56 & 538 & 63.6 \\
$\begin{array}{l}\text { Posts and Comments } \\
\text { with Intrinsic Value } \\
\begin{array}{l}\text { Posts and Comments } \\
\text { without Intrinsic }\end{array}\end{array}$ & 5269 & 67.5 & 154 & 44 & 187 & 44 & 308 & 36.4 \\
$\begin{array}{l}\text { Value } \\
\text { Total }\end{array}$ & 7807 & 100 & 350 & 100 & 425 & 100 & 846 & 100
\end{tabular}

When analyzing only posts and comments by political actors, results reveal that only about $20 \%$ of the postings of HC Strache (FPÖ Vienna) and The Greens Vienna and about $45 \%$ of the postings of Christine Marek (ÖVP Vienna) and the SPÖ Vienna contribute to the quality of deliberation on the Web (Table 5). Most messages by political actors on Facebook are just an invitation to an event or a link to another source of information. 
Table 5. Number of Posts and Comments by Political Actors with Intrinsic Value

\begin{tabular}{|c|c|c|c|c|c|c|c|c|}
\hline & \multicolumn{2}{|c|}{$\begin{array}{l}\text { HC Strache } \\
\text { (FPÖ } \\
\text { Vienna) }\end{array}$} & \multicolumn{2}{|c|}{$\begin{array}{l}\text { The Greens } \\
\text { Vienna }\end{array}$} & \multicolumn{2}{|c|}{$\begin{array}{l}\text { Christine } \\
\text { Marek (ÖVP } \\
\text { Vienna) }\end{array}$} & \multicolumn{2}{|c|}{ SPÖ Vienna } \\
\hline & $\mathrm{N}$ & $\%$ & $\mathrm{~N}$ & $\%$ & $\mathrm{~N}$ & $\%$ & $\mathrm{~N}$ & $\%$ \\
\hline $\begin{array}{l}\text { Posts and Comments } \\
\text { with Intrinsic Value }\end{array}$ & 17 & 20 & 29 & 21 & 36 & 48 & 45 & 43 \\
\hline $\begin{array}{l}\text { Posts and Comments } \\
\text { without Intrinsic Value }\end{array}$ & 69 & 80 & 106 & 79 & 40 & 52 & 60 & 57 \\
\hline Total & 86 & 100 & 135 & 100 & 75 & 100 & 105 & 100 \\
\hline
\end{tabular}

\subsection{The Quality of Understanding of Political Discourse}

\section{Level of the Quality of Understanding of Facebook Discussions}

Finally, the index of a quality of understanding for the input of political actors on each Facebook site was measured by analyzing all posts and comments, which are promoting rational critical discourse; i.e. postings with intrinsic value. As shown above, this only applies to a small number of postings of political actors. All postings were coded on the four indicators of the index of a quality of understanding: statement of reasons, proposals for solutions, respect and doubts.

Table 6. Index of a Quality of Understanding for Postings of Political Actors

\begin{tabular}{lcc}
\hline Facebook site & $\begin{array}{c}\text { Number of post/com- } \\
\text { ments with intrinsic } \\
\text { value }\end{array}$ & $\begin{array}{c}\text { Index of a Quality of } \\
\text { Understanding* }\end{array}$ \\
\hline HC Strache (FPÖ Vienna) & 17 & 3.76 \\
The Greens Vienna & 29 & 4.14 \\
Christine Marek (ÖVP & 36 & 4.28 \\
Vienna) & 45 & 4.4 \\
SPÖ Vienna & & \\
\hline
\end{tabular}

*Per unit of analysis (post or comment) the minimum number of points is 0 , the maxi-
mum number of points is 10 ; therefore, the maximum index score is 10 points. To allow
for quantitative comparison, the scores were aggregated to an index, summarizing the
results for each indicator of a quality of understanding (statement of reasons, proposals
for solutions, respect, and doubts) for each Facebook site and then were divided by the
maximum value that could be reached for each indicator.

Comparing the input of the four political actors across the four analyzed Facebook sites, results reveal that the level of the quality of understanding does not differ to a great extent between the objects of investigation (Table 6). With an index of 4.4 the SPÖ Vienna scored highest. Less than any other political actor was HC Strache critical examining the political discussion and contributing to a deliberative discussion: The analysis of posts and comments by HC Strache reveals an index of 3.76 .

Table 7 displays the scores for each indicator of a quality of understanding for each Facebook site. The results for the indicator statement of reasons illustrate that about half of all postings were not supported by an argumentation, except for the postings of HC Strache. For HC Strache this only applies to about a quarter of the postings. About half of the postings on the Facebook site of HC Strache were supported by a generalized statement of reasons. The highest level of justification (mainly simple statement of reasons) was found in the postings of The Greens Vienna. On the contrary, The Greens Vienna introduced only a very few proposals of solutions. Only four of the 29 postings with an intrinsic value revealed an idea or concept to solve a problem under debate. Overall, political actors did not present many proposals for solutions in the online discourse. The most precise proposals of solutions (highest level) were given by the SPÖ Vienna ( 8 of 45 ). The comparison also demonstrates a similar communication strategy for the indicator respect for the three parties, The Greens Vienna, Christine Marek (ÖVP) and SPÖ Vienna, as seen for the indicator statement of reasons. In almost all postings they maintained a degree of mutual respect with their fellow participants. On the contrary, HC Strache was quite respectless in his postings (in 7 of 17 postings). Similar results were found for the indicator doubts. The Greens, Christine Marek (ÖVP) and the SPÖ Vienna hardly ever cast doubt on other participants and their messages; whereas HC Strache cast doubt, in particular, on other participants' actions and behavior (in 7 of 17 postings). The results show that in the majority of postings, in which the political actors have cast doubt, it had been in regard to other actors' legitimacy.

Table 7. Scores by Indicators of a Quality of Understanding for Postings of Political Actors

\begin{tabular}{|c|c|c|c|c|c|c|c|}
\hline $\begin{array}{l}\text { Statement of } \\
\text { Reasons }\end{array}$ & Value & $\begin{array}{l}\text { Stra- } \\
\text { che } \\
\text { (FPÖ) }\end{array}$ & $\begin{array}{c}\text { The } \\
\text { Greens } \\
\text { Vienna }\end{array}$ & $\begin{array}{c}\text { Marek } \\
\text { (ÖVP) }\end{array}$ & $\begin{array}{c}\text { SPÖ } \\
\text { Vienna }\end{array}$ & $\mathrm{N}$ & $\%$ \\
\hline & 0 & 4 & 14 & 18 & 19 & 55 & 43.3 \\
\hline & 1 & 8 & 3 & 7 & 14 & 32 & 25.2 \\
\hline & 2 & 3 & 11 & 9 & 9 & 32 & 25.2 \\
\hline & 3 & 2 & 1 & 2 & 3 & 8 & 6.3 \\
\hline & total & 17 & 29 & 36 & 45 & 127 & 100 \\
\hline \multirow[t]{5}{*}{$\begin{array}{l}\text { Proposals for } \\
\text { Solutions }\end{array}$} & Value & $\begin{array}{l}\text { Stra- } \\
\text { che } \\
\text { (FPÖ) }\end{array}$ & $\begin{array}{c}\text { The } \\
\text { Greens } \\
\text { Vienna }\end{array}$ & $\begin{array}{c}\text { Marek } \\
\text { (ÖVP) }\end{array}$ & $\begin{array}{c}\text { SPÖ } \\
\text { Vienna }\end{array}$ & $\mathrm{N}$ & $\%$ \\
\hline & $\mathrm{o}$ & 13 & 25 & 25 & 32 & 95 & 74.8 \\
\hline & 1 & 1 & 2 & 10 & 5 & 19 & 15.0 \\
\hline & 2 & o & 2 & 1 & 8 & 13 & 10.2 \\
\hline & total & 17 & 29 & 36 & 45 & 127 & 100 \\
\hline \multirow[t]{5}{*}{ Respect } & Value & $\begin{array}{l}\text { Stra- } \\
\text { che } \\
\text { (FPÖ) }\end{array}$ & $\begin{array}{l}\text { The } \\
\text { Greens } \\
\text { Vienna }\end{array}$ & $\begin{array}{c}\text { Marek } \\
\text { (ÖVP) }\end{array}$ & $\begin{array}{c}\text { SPÖ } \\
\text { Vienna }\end{array}$ & $\mathrm{N}$ & $\%$ \\
\hline & 0 & 7 & 2 & 2 & 3 & 14 & 11.0 \\
\hline & 3 & 10 & 27 & 34 & 41 & 112 & 88.2 \\
\hline & 4 & 0 & o & o & 1 & 1 & 0.8 \\
\hline & total & 17 & 29 & 36 & 45 & 127 & 100 \\
\hline \multirow[t]{5}{*}{ Doubts } & Type & $\begin{array}{l}\text { Stra- } \\
\text { che } \\
\text { (FPÖ) }\end{array}$ & $\begin{array}{c}\text { The } \\
\text { Greens } \\
\text { Vienna }\end{array}$ & $\begin{array}{c}\text { Marek } \\
\text { (ÖVP) }\end{array}$ & $\begin{array}{c}\text { SPÖ } \\
\text { Vienna }\end{array}$ & $N$ & $\%$ \\
\hline & $\begin{array}{c}\text { no } \\
\text { doubt }\end{array}$ & 7 & 25 & 31 & 36 & 99 & 78 \\
\hline & $\begin{array}{l}\text { intelli- } \\
\text { gibility }\end{array}$ & o & 0 & 0 & 0 & 0 & 0 \\
\hline & truth & 1 & o & 0 & o & 1 & 0.8 \\
\hline & $\begin{array}{l}\text { truth- } \\
\text { fulness }\end{array}$ & 2 & o & 1 & 1 & 4 & 3.1 \\
\hline
\end{tabular}




\begin{tabular}{rrrrrrr}
$\begin{array}{r}\text { legiti- } \\
\text { macy }\end{array}$ & 7 & 4 & 4 & 8 & 23 & 18.1 \\
\hline total & 17 & 29 & 36 & 45 & 127 & 100 \\
\hline
\end{tabular}

In general, during the 2010 Viennese election campaign political actors did not follow the principles of a quality of understanding to a great extent in their online communication with citizens on Facebook. Political actors did not express many doubts. There was not a great argumentative discourse in the Facebook communities and political actors actually shared only a very few proposals for solutions in discussions.

\section{Engagement of Participants}

Based on the theoretical notion that the better people understand the message, the more they will be able to engage in the political discourse, the proposed hypothesis stated that the more political actors follow the principles of a quality of understanding in their online political discussion, the more will Facebook participants join the political discourse. For the three smaller communities the results support the hypothesis as illustrated in Figure 6. Yet, this does not apply to the big community of HC Strache.

Figure 6. Quality of Understanding of the Political Discourse and Engagement of Participants

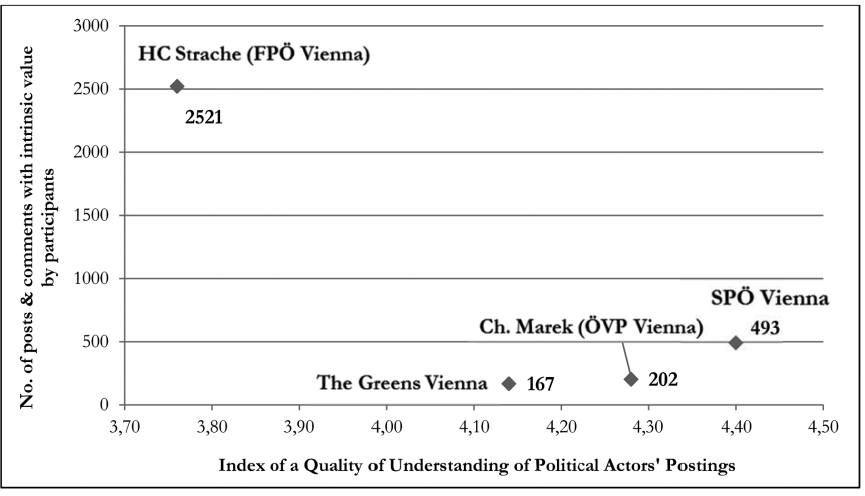

\subsection{Discussion}

This study found that online deliberation is dominated by a very few people in the online community. The majority of people are eavesdropping (Locke, 2010). Participants are just observing the political discourse between politics and citizens and between citizens. They rather read than write. By using Facebook citizens increasingly have the chance to directly participate in the democratic process on a regular basis, but the contribution is (still) limited. This seems to be a general problem for the conditions of political discourse in the virtual world as outlined by other research on the democratic potential of discussion groups and discussion lists (see above). For example, based on the analysis of group dialogue on the UK Citizens Online Democracy Dahlberg (2001 b) notes, even when deliberative options for the discussion with fellow citizens are available most people are not interested in them. Most citizens rather chose face-to-face communication with their representatives than online interaction.
The size of the Facebook community has no influence on this condition: The number of fans of a Facebook community does not increase the number of active participants. Results rather show that smaller political Facebook pages have more active participants. This might be due to the fact that opinion leaders want to speak up in public. Social media gives them a new space and they probably take this opportunity before most citizens. Therefore, active participants might be among the first network members. People who are joining afterwards (when the community is growing fast) are more likely just eavesdropping on the political discussion.

The communication strategy of political actors is on the one hand very similar, on the other hand it seems as political actors use Facebook for different purposes. The number of posts which can initiate a new discussion string was quite similar for the four political actors over the course of the campaign. This form of communication, i.e. publishing a post, is related to a top-down information strategy. By starting a new discussion string political actors control the flow of communication to a great extent. Primarily, social media is used as instrument to inform citizens just like all other campaign communication channels. This is also confirmed when examining the content posted by political actors in posts and comments. The majority of postings on Facebook included only an invitation to an event or a link to another source of information (e.g. mass media). Informing is one of the primary communication goals of political parties and candidates in campaigns. In general, it seems as political actors primarily use Facebook as a communication instrument to inform citizens about events in the offline world rather than engaging in a political discussion with them.

The usage of an information strategy on a communication channel like social media, which enhances direct communication, might also be due to the fact of a lack of experience with this new communication tool. After all, the 2010 Austrian regional election campaign was the first campaign, in which Austrian political parties and top candidates used Facebook to communicate with citizens on a wider scale. Further study of the communication strategy of political actors online would help us to find reasons for this communication behavior. The Greens Vienna were to a greater extent involved in the online communication with citizens than any other party as revealed by the high number of comments. They fostered a more dialogue approach; thereby, using the deliberative potential of social media. Why The Greens Vienna and not any other party? The party always seems to adopt innovative communication strategies first. Also in terms of website usage The Greens (The Austrian Green Party) show greater use of web features that enhance participation with and mobilization of voters (citizens) (Rußmann, 2011).

The quality of the political input is measured in light of four indicators based on the literature concerning deliberative democracy. Overall, the contribution by political actors does not promote the idea of a deliberative democracy on the Internet. Only about half of all messages, and in the case of HC 
Strache, only a third of all postings have an intrinsic value to the political discourse. Moreover, the index score of a quality of understanding for these postings is rather low. Results for the index of a quality of understanding range between 3.76 and 4.4. (The highest possible score for the index of a quality of understanding are 10 points.) Taking a closer look at the results for each indicator, results reveal that HC Strache was relatively disrespectful in his postings and to a greater extent he has cast doubt on other participants, in particular on the trustworthiness and legitimacy of others. Such postings tend to polarize people's opinions. A typical focus of the communication strategy of HC Strache and the right-wing populist Freedom Party of Austria. On the contrary, the other political actors were trying to avoid any confrontation. This might be due to the fact that in election times they are in competition to secure votes and do not want to be involved in a conflict.

Overall, political actors are not even at an intermediary stage in terms of using the deliberative potential of social media. Following Dahlberg (2001 a, p. 6) particularly in comparison to face-to-face communication, online exchange may be seen as facilitating reflexivity. Written communication compared to spoken communication often encourages people to think more carefully about what they want to say: Before taking a position in a public discussion they reflect carefully, considering ongoing arguments. The question that arises is if political actors hardly express relevant doubts, they hardly justify their statements, they hardly present proposals for solutions and they hardly deal with other political actors (and others) in a more or less respectful way to what extent are they actually interested in a discussion about political issues with citizens? This question seems to be relevant as the determining factor for political actors' contribution to a deliberative discussion seems to be their motivation. The presented results reveal that the quality of understanding of political actors' postings is not depending on (basic) conditions such as the size of the community, the number of active participants, the number of posts nor the lifespan of the community.

\section{Conclusion}

The goal of this research is to give us a better understanding of how people participate in the political process using Facebook during election campaigns. In conclusion, the study has demonstrated that quantitatively and qualitatively online communication is not oriented to any great extent towards communicative principles that can promote the development of a deliberative public sphere. Just like in the offline world, in the virtual world only a very few citizens participate in politics and engage with politicians. Considering that this study has been conducted during election campaigns, which are times of intensive public discussion about political issues, the results are less promising for everyday political communication. However, we always have to consider that the many lurkers are following the online discussion on public opinion and thereby, they might have an impact on political development, in general (Papacharissi, 2004). Future studies should analyze the flow of online political discourse further to observe its impact on offline political discussion.

The main objective of this research was to investigate to what extent the online political discourse is actually following qualitative principles demanded by the public sphere conception; thereby trying to better understand the notion of deliberation in the online world. By quantifying the quality of deliberation, this study found that only about half or even less of the online communication is distributing information that has sophisticated means to the political discussion. Even on Facebook sites of political actors communication is mainly used to exchange information considering the offline world (such as postings about events). Moreover, the actual online political discussion is not dominated by the principles of a quality of understanding. Albeit the fact that in smaller communities there is a tendency toward greater engagement in the political discussion by Facebook participants (fans), the more the communicative input of political actors follows the principles of a quality of understanding. Citizens need to understand political actors' messages in order to participate in the political discussion and develop their own opinions. In the process of public discourse ideally political actors have to justify their positions, they should present proposals for solutions for the discussed problems, be respectful when engaging with others and express relevant doubts concerning positions as well as other political actors. Thereby, politics may foster rational critical discourse among participants in the virtual world.

Public sphere is a necessary condition for democracy, future studies should observe online political discussion further to determine which political issues enhance a greater quality of understanding, in which way the mass media influences the online political discourse and what role opinion leaders play in a decentralized communication structure. Therefore, we need to know more about the participants in the online community. We will investigate the quality of understanding in postings published by citizens in the near future. The question remains whether the quality of understanding of postings of political actors positively influences the quality of understanding of postings of fans.

\section{References}

Brants, K. (2005). Guest Editor's Introduction: The Internet and the Public Sphere. Political Communication, 22(2), 143-146.

Burkart, R., \& Russmann, U. (2009). Qualität des öffentlichen politischen Diskurses in der österreichischen Wahlkampfkommunikation (1966-2008). Codebuch für die Inhaltsanalyse der Presseaussendung und der Zeitungsberichterstattung. Wien.

Burkart, R., \& Russmann, U. (2010). Journalism, Democracy and the Role of Doubts: An Analysis of Political Campaign Communication in Austria. Studies in Communication Sciences, 10(1), 11-27.

Burkart, R., Rußmann, U., \& Grimm, J. (2010). Wie verständigungsorientiert ist Journalismus? Ein Qualitätsindex am Beispiel der Berichterstattung über Europa im österreichischen Nationalratswahlkampf 2008. In H. Pöttker \& Ch. Schwarzenegger (Eds.), Europäische Öffentlichkeit und journalistische Verantwortung (pp. 256-281). Köln: Herbert van Halem. 
Coleman, S., Hall, N., \& Howell, M. (2002). Hearing Voices. The Experience of Online Public Consultation and Discussion in UK Governance. London: Hansard Society.

Dahlberg, L. (2001 a). Computer-Mediated Communication and Public Sphere: A Critical Analysis. Journal of Computer-Mediated Communication, 7(1).

Dahlberg, L. (2001 b). The Internet and Democratic Discourse: Exploring the Prospects of Online Deliberative Forums for Extending the Public Sphere. Information, Communication and Society 4(4), 615-633.

Dahlgren, P. (2005). The Internet, Public Spheres, and Political Communication: Dispersion and Deliberation. Political Communication, 22(2), 147-162.

Der Standard (2012). Ein Ruheloser an den wichtigen Hebeln. Retrieved September 4, 2012, from http://derstandard.at/3211104

Die Presse. (2012). Strache: "SPÖ ist Islamisten-Partei". Retrieved September 4, 2012, from http://diepresse.com/home/politik/wienwahl/ 588632/Strache_SPOe-ist-IslamistenPartei.

Etzioni, A., Laudon, K., \& Lipson, S. (1975). Participatory Technology: The MINERVA Communications Tree. Journal of Communication, 25(2), 64-74.

Ferree, M. M., Gamson, W. A., Gerhards, J. \& Rucht, D. (2002). Shaping Abortion Discourse. Democracy and the Public Sphere in Germany and the United States. Cambridge University Press.

Gastil, J. (2008). Political Communication and Deliberation. Thousand Oaks: Sage.

Gerhards, J. (2003). Diskursanalyse als systematische Inhaltsanalyse. Die öffentliche Debatte über Abtreibung in den USA und in der Bundesrepublik im Vergleich. In R. Keller, A. Hirseland, W. Schneider \& W. Viehöver (Eds.), Handbuch Sozialwissenschaftliche Diskursanalyse. Band II: Forschungspraxis (pp. 299-324). Opladen: Leske und Buderich.

Gerhards, J., Neidhardt, F., \& Rucht, D. (1998). Zwischen Palaver und Diskurs: Strukturen öffentlicher Meinungsbildung am Beispiel des Abtrei bungsdiskurses in der Bundesrepublik. Opladen: Westdeutscher Verlag.

Gonzalez-Bailon, S., Kaltenbrunner, A., \& Banchs R. E. (2010). The structure of political discussion networks: a model for the analysis of online deliberation. Journal of Information Technology, 25, 230-243.

Gueorguieva, V. (2008). Voters, MySpace, and YouTube: The Impact of Alternative Communication Channels on the 2006 Election Cycle and Beyond. Social Science Computer Review, 26(3), 288-300.

Gutmann, A., \& Thompson, D. (1990). Moral Conflict and Political Consensus. Ethics, 101, 64-88.

Habermas, J. (1970). Towards a theory of communicative competence. Inquiry. An Interdisciplinary Journal of Philosophy, 13(1-4), 360-375.

Habermas, J. (1984). The Theory of Communicative Action Vol. 1. Reason and the Rationalization of Society. Boston: Beacon Press.

Habermas, J. (1987). The Theory of Communicative Action. Volume 2. Lifeworld and system: A critique of functionalist reason. Boston: Beacon Press.

Habermas, J. (1992). Faktizität und Geltung: Beiträge zur Diskurstheorie des Rechts und des demokratischen Rechtsstaats. Frankfurt am Main: Suhrkamp.

Habermas, J. (2001). On the Pragmatics of Social Interaction: Preliminary Studies in the Theory of Communicative Action. Cambridge: Polity.

Hagemann, C. (2002). Participants in and contents of two Dutch politica party discussion lists on the Internet. Javnost - The Public, 9(2), 61-76.

Karppinen, K., Moe, H., \& Svensson, J. (2008). Habermas, Mouffe and Political Communication. A Case for theoretical Eclecticism. Javnost The Public, 15(3), 5-22.

Koop, R., \& Jansen H. J. (2009). Political Blogs and Blogrolls in Canada: Forums for Democratic Deliberation? Social Science Computer Review, 27(2), 155-173.

Locke, J. L. (2001). Eavesdropping. An Intimate History. New York: Oxford University Press.
Lup, O. (2010). The role of political discussion in developing democracies: evidence from Hungary. In M. R. Wolf, L. Morales \& K. Ikeda (Eds.), Political Discussion in Modern Democracies. A comparative perspective (pp. 183-200). Oxon: Routledge.

Mouffe, C. (2000). Deliberative Democracy or Agnostic Pluralism. Political Science Series. Vienna: Institute for Advanced Studies.

Papacharissi, Z. (2004). Democracy online: civility, politeness, and the democratic potential of online political discussion groups. New Media \& Society, 6(2), 259-283.

Ruiz, C., Domingo, D., Micó, J. L., Díaz-Noci, J., Meso, K., \& Masip, P. (2011). Public Sphere 2.0? The Democratic Qualities of Citizen Debates in Online Newspapers. The International Journal of Press/Politics, 16(4), 463-487.

Ruß-Mohl, S. (1994). Der I-Faktor. Qualitätssicherung im amerikanischen Journalismus. Modell für Europa? Zürich: Edition Interfrom.

Rußmann, U. (2011). Web-Wahlkampf in Deutschland und Österreich. In J. Wolling, Jens, A. Will \& Ch. Schumann (Eds.): Medieninnovationen. Wie Medienentwicklungen die Kommunikation in der Gesellschaft verändern (pp. 137-155). Konstanz: UVK Verlagsgesellschaft.

Rußmann, U. (2012). Verständigungsorientierte Kommunikationsprozesse in der öffentlichen politischen Diskussion. Das VÖA-Modell in der Wahlkampfkommunikation. In W. Hömberg, D. Hahn \& T. B. Schaffer (Eds.), Kommunikation und Verständigung. Theorie - Empirie - Praxis. Festschrift für Roland Burkart (pp. 171-182). 2. durchgesehene und überarbeitete Auflage. Wiesbaden: VS Verlag.

Semetko, H. A. (2008). Election Campaign Communication. In W. Donsbach (Ed.), The International Encyclopedia of Communication. London: Blackwell Publishing.

Spörndli, M. (2003). Discourse Quality and Political Decisions: An Empirical Analysis of Debates in the German Conference Committee. Berlin: Social Science Research Center Berlin, WZB. Retrieved from: http:// skylla.wz-berlin.de/pdf/2003/iv 03-101.pdf

Spörndli, M. (2004). Diskurs und Entscheidung. Eine empirische Analyse kommunikativen Handelns im deutschen Vermittlungsausschuss. Wiesbaden: VS-Verlag.

Steenbergen, M. R., Bächtiger, A., Spörndli, M., \& Steiner, J. (2003). Measuring Political Deliberation: A Discourse Quality Index. Comparative European Politics, 1, 21-48.

Strandberg, K. (2008). Public Deliberation Goes On-Line? An Analysis of Citizens' Political Discussions on the Internet prior to the Finish Parliamentary Elections in 2007. Javnost - The Public, 15(1), 71-90.

Williams, C. B., \& Gulati, G. J. (2007). Social Networks in Political Campaigns: Facebook and the 2006 Midterm Elections. Retrieved from: http:// www.academia.edu/281042.

Witschge, T. (2008). Examing Online Public Discourse in Context: A Mixed Method Approch. Javnost - The Public, 15(2), 75-92.

Wright, S. (2012). Politics as usual? Revolution, normalization and a new agenda for online deliberation. New Media \& Society, 14(2), 244-261.

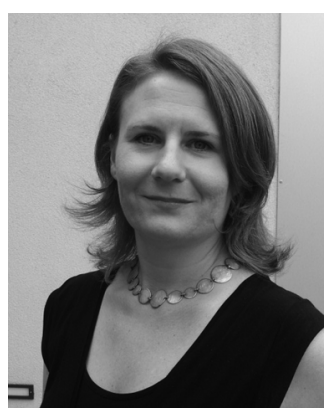

Prof. Dr. Uta Rußmann is Professor at the Department of Communication, Marketing and Sales at the FHWien University of Applied Sciences of WKW, Vienna. She studied communication and media sciences, sociology and political science at Vienna and Tampere and was a postdoc researcher at the Universities of Vienna and Innsbruck. E-Mail: uta.russmann@fh-wien.ac.at. 